\title{
Morphological docking of secretory vesicles
}

\author{
Heidi de Wit
}

Accepted: 25 May 2010/Published online: 26 June 2010

(C) The Author(s) 2010. This article is published with open access at Springerlink.com

\begin{abstract}
Calcium-dependent secretion of neurotransmitters and hormones is essential for brain function and neuroendocrine-signaling. Prior to exocytosis, neurotransmitter-containing vesicles dock to the target membrane. In electron micrographs of neurons and neuroendocrine cells, like chromaffin cells many synaptic vesicles (SVs) and large dense-core vesicles (LDCVs) are docked. For many years the molecular identity of the morphologically docked state was unknown. Recently, we resolved the minimal docking machinery in adrenal medullary chromaffin cells using embryonic mouse model systems together with electron-microscopic analyses and also found that docking is controlled by the sub-membrane filamentous (F-)actin. Currently it is unclear if the same docking machinery operates in synapses. Here, I will review our docking assay that led to the identification of the LDCV docking machinery in chromaffin cells and also discuss whether identical docking proteins are required for $\mathrm{SV}$ docking in synapses.
\end{abstract}

Keywords Docking - Electron microscopy $\cdot$ F-actin · Munc18-1 - SNARE proteins - Synaptotagmin-1 . Secretory vesicles

Robert Feulgen Prize 2010 Winner lecture presented at the 52nd Symposium of the Society for Histochemistry in Prague, Czech Republic, 1-4 September 2010.

\section{H. de Wit $(\square)$}

Department of Functional Genomics, Center for Neurogenomics and Cognitive Research, Neuroscience Campus Amsterdam, VU University Medical Center, VU University Amsterdam, De Boelelaan 1085, 1081 HV Amsterdam, The Netherlands e-mail: heidi.de.wit@cncr.vu.nl

\author{
Abbreviations \\ BoNT/C Botulinum toxin C \\ $\mathrm{Ca}^{2+} \quad$ Calcium \\ EM Electron microscopy \\ F-actin Filamentous actin \\ Lat A Latrunculin A \\ LDCV Large dense-core vesicle \\ MARCKs Myristoylated alanine-rich C kinase substrate \\ PKC Protein kinase C \\ SFV Semliki-Forest-Virus \\ SNAP-25 Synaptosome-associated protein of $25 \mathrm{kDa}$ \\ SNARE Soluble $N$ ethylmaleimide-sensitive factor \\ (NSF) attachment protein receptor \\ SV Synaptic vesicle \\ VAMP-2 Vesicle-associated membrane protein-2
}

\section{Introduction}

Calcium $\left(\mathrm{Ca}^{2+}\right)$-dependent exocytosis of synaptic vesicles (SVs) can be elicited within fractions of a millisecond upon calcium-influx into the releasing cell. In order to achieve such exquisite temporal precision, secretory vesicles undergo a number of maturation steps before calcium influx. Neuroendocrine cells like chromaffin cells are established models for neurotransmitter release (Morgan and Burgoyne 1997). These cells secrete adrenalin and noradrenalin that are both accumulated in large dense-core vesicles (LDCVs), which are recognized in electron microscopic (EM) pictures by a vesicular membrane containing an electron dense-core (Voets et al. 2001). Docking is considered the first necessary intermediate maturation step before either LDCVs or SVs gain fusion-competence 
and release their neurotransmitters. Recently, it was shown that only a fraction of docked SVs fuse upon $\mathrm{Ca}^{2+}$-influx (Wadel et al. 2007) and that their release-readiness seems determined by their proximity to $\mathrm{Ca}^{2+}$-channels (Sakaba and Neher 2001). Fusion involves the evolutionarily conserved soluble $N$ ethylmaleimide-sensitive-factor-attachment-protein-receptor (SNARE)-complex (Ferro-Novick and Jahn 1994; Jahn 2000). The neuronal SNARE-complex contains plasma membrane proteins syntaxin-1 and synaptosome-associated-protein of 25-kDa (SNAP-25) and vesicle-associated-membrane-protein-2 (VAMP-2)/synaptobrevin-2 (Jahn and Scheller 2006; Rizo and Rosenmund 2008). Association of the SNAREs underlies the priming reaction (Walter et al. 2010), and final C-terminal-SNAREassembly coincides with fusion-triggering (Sørensen et al. 2006). Genetic deletion of neuronal SNARE genes are lethal and has profound effects on neurotransmission (Schoch et al. 2001, 2003). Sec1/Munc18-1-related proteins (Jahn 2000) bind to the neuronal SNARE-complex (Dulubova et al. 2007) and are together with syntaxin-1 essential for docking (de Wit et al. 2006; Verhage and Sørensen 2008). Munc18-deficient mice die shortly after birth (Verhage et al. 2000). Previously we showed that deficiency of Munc18 (Voets et al. 2001) or the protein syntaxin-1 (de Wit et al. 2006) not only abolished exocytosis, but also produced robust docking phenotypes in chromaffin cells (Toonen et al. 2006a) as well as neurons (Toonen et al. 2006b). We also observed that manipulating Munc18 expressing levels affected the sub-membrane filamentous (F-)actin density (Toonen et al. 2006a) which is known to determine access of LDCVs to fusion sites (Malacombe et al. 2006). In contrast to an increasing fundamental understanding of exocytosis the molecular mechanism of docking is only slowly being unraveled (Verhage and Sørensen 2008). This review summarizes how we achieved to resolve the minimal molecular docking machinery for LDCV secretion employing a unique docking assay in which ultrastructural approaches are combined with rescue experiments in genetically modified embryonic mouse chromaffin cells. In addition, the possible mechanism by which docking proteins control access to fusion sites by modulation of sub-membrane F-actin will be discussed. Finally our results in chromaffin cells will also be compared to docking phenotypes in synapses in an attempt to see whether docking machineries are conserved in rapidly secreting cells.

\section{Morphological docking assay}

In electron micrographs of adrenal chromaffin cells, many LDCVs are found morphologically docked at the target membrane (Fig. 1). Morphologically docked vesicles are traditionally defined as those vesicles that have no measurable distance between vesicle and plasma membrane (Fig. 1), but some authors use less stringent criteria (for a review see Verhage and Sørensen 2008). We studied docking of LDCVs in mouse embryonic (embryonic day 18) chromaffin cells as a preferred docking model, because docking phenotypes are typically more evident than in other systems studied so far (for a review see Verhage and Sørensen 2008; Fig. 1). The reason why we use embryonic cells as a model system is because it seems that a genetic deletion of docking proteins results in a lethal phenotype

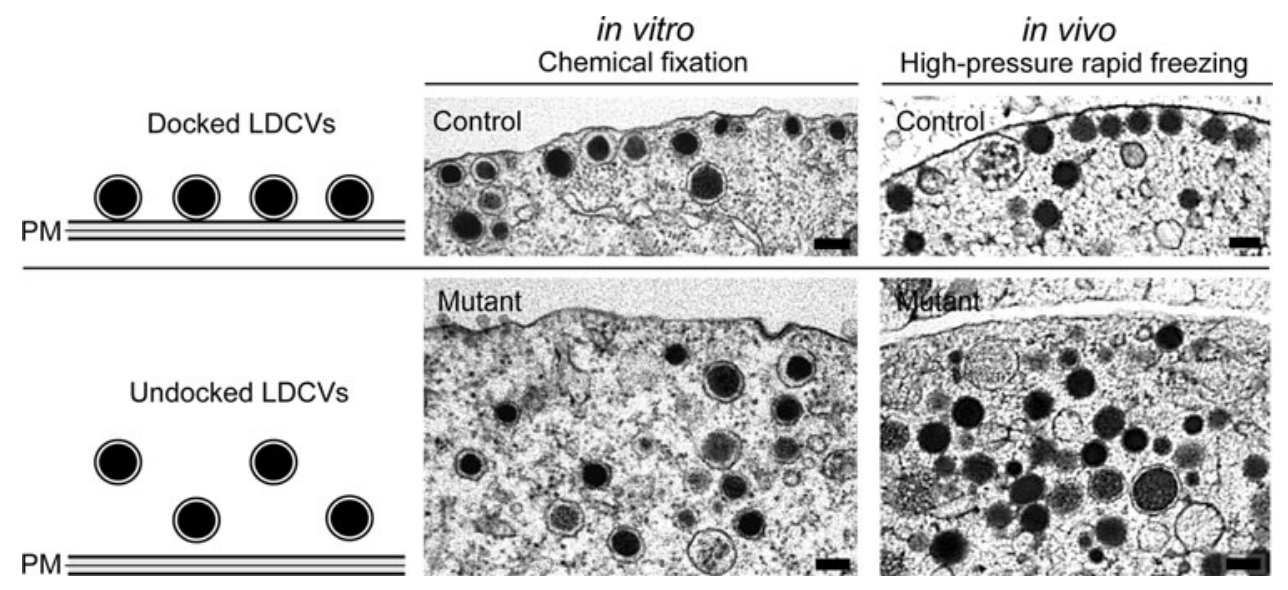

Fig. 1 Morphological docking phenotypes in chromaffin cells. Left panel schematic representation of morphological docked (top) and undocked (bottom) LDCVs, respectively without any $(0 \mathrm{~nm})$ or with $(>0 \mathrm{~nm})$ measurable distance between vesicle and plasma membrane (PM). Middle panel electron micrograph of a sub-region of the plasma membrane of a control (wild type) cultured embryonic chromaffin cell showing many morphological docked LDCVs (top). In the absence of syntaxin (mutant) LDCVs are found scattered in the cytoplasm rather than at the plasma membrane indicative of a strong docking phenotype (bottom). See (de Wit et al. 2006) for details. Right panel representative electron micrographs from SNAP-25 wild type (top) and Snap-25 null littermate (bottom) chromaffin cells in an intact medulla of the adrenal gland after high pressure rapid freezing. See (de Wit et al. 2009) for details. The scale bar represents $100 \mathrm{~nm}$ 


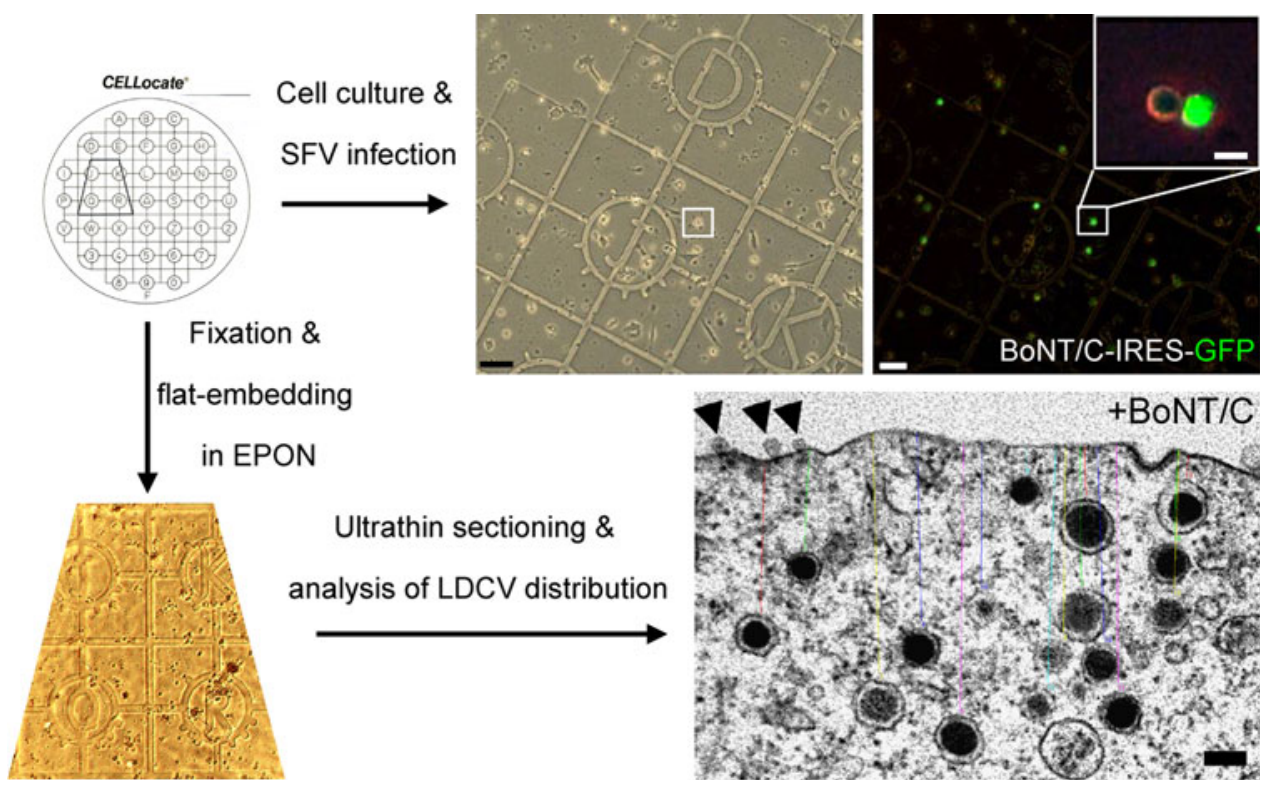

Fig. 2 Docking assay to reveal morphological docking phenotypes. Embryonic chromaffin cells are grown on Cellocate coverslips and infected with SFV constructs containing an IRES-GFP (see main text for abbreviations and details). After selection of the GFP-expressing cells on the finder-grid (bar represents 100 and $10 \mu \mathrm{m}$ in the inset), cells are flat-embedded in EPON and then after removal of the glass coverslip the region of interest is trimmed and ultrathin-sectioned.

causing death shortly after birth in all nulls studied so far (de Wit et al. 2009; Verhage and Sørensen 2008).

The first docking protein we identified was Munc18. After ultrastructural analysis of LDCV distribution we observed a tenfold reduction of 'morphologically' docked LDCVs in munc18-1 deficient chromaffin cells of intact adrenal glands (Voets et al. 2001), and which could have explained the severe secretion phenotype. In addition, we observed that gene-dose reductions in munc18-1 expression reduce docking, whereas gene-dose enhancements increase docking (Toonen et al. 2006a) indicating that Munc18-1 promotes docking. To reintroduce Munc18 we developed a primary-culture system for munc18-1 deficient chromaffin cells and readily infected those with the Munc18 gene using the Semliki-Forest-Virus (SFV) expression-system (Ashery et al. 2000; Toonen et al. 2006a). To obtain straightforward detection of infected cells based on their fluorescence we coupled the Munc18 cDNA via an internal ribosomal entry site to cDNA for green fluorescent protein (Toonen et al. 2006a) (Fig. 2). To easily find infected cells for EM analysis we grow our cells on coverslips that contain a grid (de Wit et al. 2006) which is kept after flat-embedding in the plastic resin, and can be used to select the region of interest for ultrathin sectioning and analysis of LDCV docking (Fig. 2). The analysis of LDCV distribution is usually performed manually, which is labor-intensive and subject to human
Subsequently the distance of LDCVs to the plasma membrane is analyzed to determine the number of docked vesicles. As an example the same mutant cell (wild type cells expressing the light chain of Botulinum toxin C (BoNT/C) to delete syntaxin) as in Fig. 1 is used. Note that the SFV viral particles are clearly visible at the plasma membrane (arrowheads). See for details (de Wit et al. 2006, 2009)

bias and error. Recently we developed an algorithm to automatically analyze LDCV distribution and docking in electron micrographs (van Weering et al. 2008). In addition to neuronal Munc18-1 we also expressed two ubiquitous Munc18 isoforms, Munc18-2 and Munc18-3 in munc18-1 deficient chromaffin cells. Munc18-2 and -3 have relatively low expression levels in neuroendocrine cells (Hata and Südhof 1995; Tellam et al. 1995). Munc18-2 is involved in histamine secretion in mast cells (Martin-Verdeaux et al. 2003) and apical vesicle trafficking in epithelial cells (Riento et al. 2000), whereas Munc18-3 regulates cell surface expression of GLUT4 in adipocytes (Latham et al. 2006; Tellam et al. 1997). The amino acid sequence homology between Munc18-1 and -2 is greater than $(60 \%)$ that of Munc18-3 (50\%), and both Munc18-1 and -2 show strong affinity for syntaxin-1, -2 , and -3, but not syntaxin-4 (Hata and Südhof 1995). Munc18-3 shows only high affinity for syntaxin-2 and -4 (Tellam et al. 1997). We found that Munc18-2 rescues the severe docking phenotype of munc18-1 null chromaffin cells indistinguishably from Munc18-1 while the more downstream vesicle priming steps are still impaired (Gulyás-Kovács et al. 2007). This suggests that Munc18-1 is additionally involved in priming vesicles for release. On the other hand docking is rescued only partially after Munc18-3 expression in munc18-1 null chromaffin cells (de Wit 2010). 
The second docking protein we identified is the SNARE protein syntaxin-1. Like Munc18 we observed that deficiency of syntaxin-1 also produced robust docking phenotypes in chromaffin cells (de Wit et al. 2006). It is known that Munc18-1 interacts with syntaxin-1 and we therefore assumed that Munc18-1's docking function depends on syntaxin-1-interaction (de Wit et al. 2006; Gulyás-Kovács et al. 2007). Munc18-1 can interact with syntaxin in two distinct binding modes: either with isolated syntaxin-1 alone in a 'closed' conformation or with syntaxin-1 in an 'open' conformation in the assembled SNARE-complex (Toonen and Verhage 2007). However, it's unclear which binding mode is essential in docking. Munc18-1 binding to open-syntaxin-1 involves the N-terminal-H(abc)-domain of syntaxin-1 (Dulubova et al. 2007; Dulubova et al. 1999; Khvotchev et al. 2007). We have previously shown that $\mathrm{N}$-terminal-interaction is not sufficient for docking, since chromaffin cells from open-syntaxin-knock-in mice show a similar docking phenotype as syntaxin-1 and munc18-1 null (Gerber et al. 2008). In addition, Munc18-1 bearing a mutation that perturbs closed-syntaxin interaction [D34N/ M38V] (Naren et al. 1997; Schütz et al. 2005) cannot restore docking in munc18-1 null cells (Gulyás-Kovács et al. 2007). Other researchers have shown that Munc18-1 binding to open-syntaxin executes fusion (Barclay 2008; Burkhardt et al. 2008; Deak et al. 2009; Dulubova et al. 2007; Khvotchev et al. 2007; Shen et al. 2007). Together, our observations show that Munc18-1 and -2 promote docking by binding to closed-syntaxin-1 while a distinct interaction mode seems required to regulate the consecutive priming step.

In addition to syntaxin-1 and Munc18-1, several other proteins have been implicated in docking in several types of secretory cells, such as rab3 and rab27, rabphilin3A, granuphilin, and exophilin4/Slp2a, and function mutations in several priming genes in $C$. elegans (RIM/unc-10, (M)unc-13, or CAPS/unc-31) produce a strong reduction of vesicles with a "contact patch" (for a review, see Verhage and Sørensen 2008). However, it seems that those proteins are not essential for LDCV docking in chromaffin cells (Ashery et al. 2000; van Weering et al. 2007), therefore we searched for other likely candidate docking proteins that together with Munc18 and syntaxin-1 form the minimal docking machinery (de Wit et al. 2009).

\section{Minimal docking machinery}

Previously we hypothesized that Munc18 promotes the formation of a docking acceptor at the plasma membrane (Voets et al. 2001) and we assumed that this docking acceptor consists of syntaxin (de Wit et al. 2006). Other researchers have shown that prior to binding of synaptobrevin-2 to syntaxin-1/SNAP-25 at the target membrane, syntaxin-1 is believed to form a 1:1-heterodimer with SNAP-25 as an intermediate step (Fasshauer and Margittai 2004; Zilly et al. 2006). Recently we found that overexpression of either SNAP-25 or a C-terminal peptide of synaptobrevin-2 that was known to favor the formation of SNAP-25/syntaxin-heterodimers in a 1:1 stoichiometry (Fasshauer and Margittai 2004; Pobbati et al. 2006) rescued docking in munc18-1 null chromaffin cells (de Wit et al. 2009) (Fig. 3). Therefore, we concluded that Munc18-1 promotes formation of docking acceptor complexes of syntaxin/SNAP-25 in chromaffin cells (Fig. 3) (de Wit et al. 2009). Since vesicle fusion is still impaired after overexpression of either SNAP-25 or a C-terminal peptide of synaptobrevin-2 we assumed that in addition to docking, Munc18-1 plays a critical function in downstream events leading to exocytosis (de Wit et al. 2009) (Fig. 3). The involvement of syntaxin-1/SNAP-25 acceptor complexes in docking suggests a direct requirement for SNAP-25 in docking, similar to syntaxin-1. However, previous observations argued against a docking function for SNAP-25 (Sørensen et al. 2003). Therefore, we decided to reanalyze docking in Snap-25 null cells. Indeed, Snap-25 deficient cells exhibited a strong docking phenotype, which was, however, slightly less severe than in Munc18-1 or syntaxin-1 deficient cells (de Wit et al. 2006; Voets et al. 2001) (Fig. 1). Different culture conditions and fixation methods could explain the observed differences to previous studies (Sørensen et al. 2003). Therefore, to circumvent possible culture or chemical fixation artifacts, we also analyzed docking in intact adrenal glands and in intact adrenal glands that were rapidly frozen under high pressure. We observed the same docking difference between Snap-25 null and wild type chromaffin cells after rapid freezing as compared to chemically fixed intact adrenal glands as well as cultured chromaffin cells (de Wit et al. 2009) (Fig. 1). In addition, we observed that overexpression of SNAP-25 on the Snap-25 null background rescued the phenotype (de Wit et al. 2009). Strikingly, in contrast to SNAP-25 overexpression in munc18-1 null cells, Munc18-1 overexpression in Snap-25 null cells did not rescue the docking phenotype (de Wit et al. 2009). Together, our observations demonstrate that SNAP-25 is the third docking protein essential for docking and that Munc18-1 cannot promote docking in its absence.

Docking of LDCVs to the SNAP-25/syntaxin acceptor complexes at the plasma membrane must involve vesicular proteins. Therefore, we next attempted to identify the vesicular component to dock vesicles to syntaxin-1/ SNAP-25 acceptor complexes. While the proteins present on SVs have been systematically identified (Takamori et al. 2006), none of these have been assigned as a docking factor; to the best of our knowledge no docking 

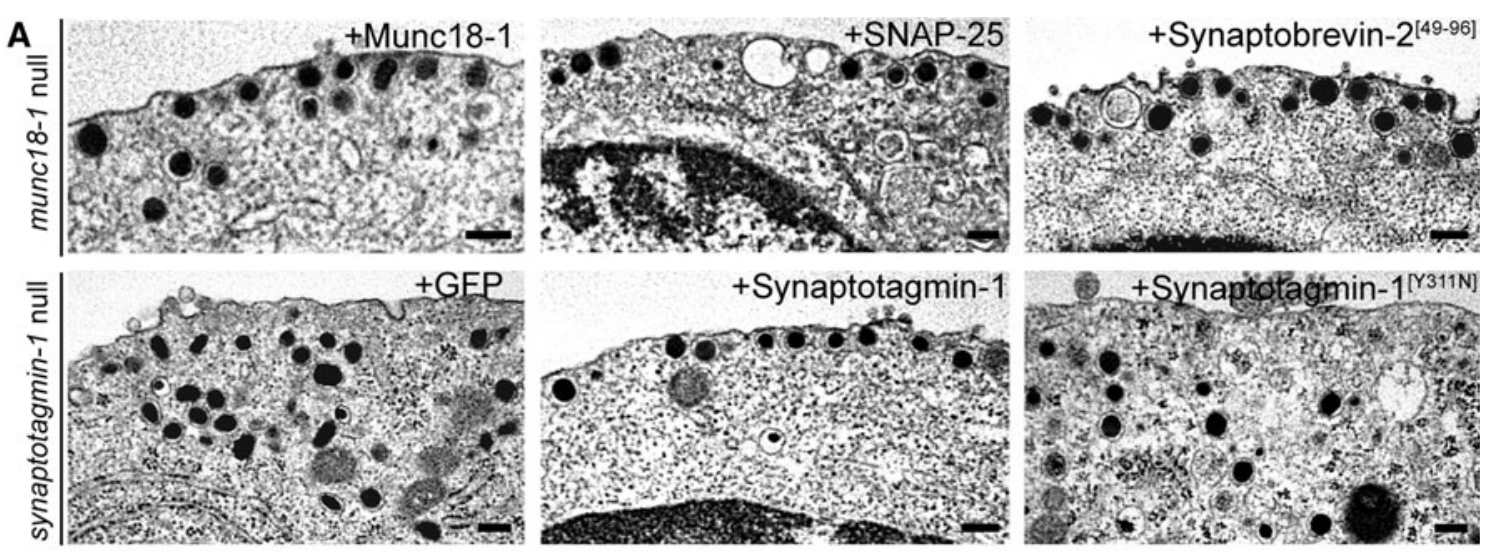

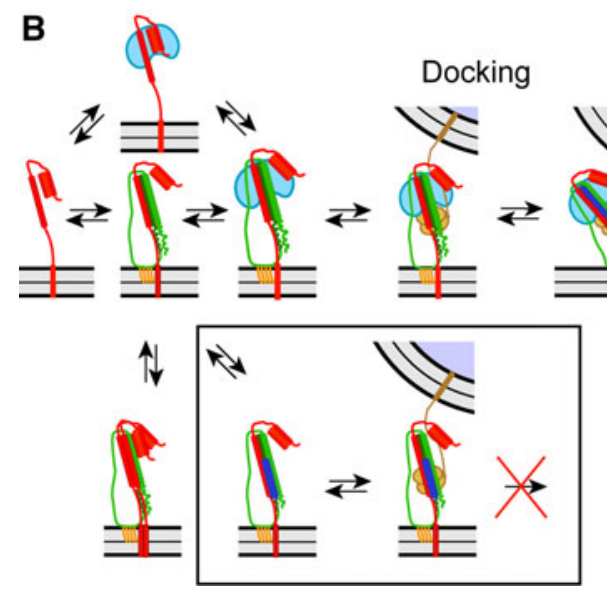

Fig. 3 Docking proteins and the minimal docking machinery. a Top panel electron micrographs from primary cultured munc18-1 null chromaffin cells expressing either Munc18-1 (left), SNAP-25 (middle) or the [49-96] C-terminal fragment of synaptobrevin-2 (right). Bottom panel electron micrographs from primary cultured synaptotagmin-1 null chromaffin cells expressing either wild type synaptotagmin-1 (middle) or the synaptotagmin-1 mutant with reduced SNAP-25 affinity [Y311N] (right) or the GFP negative control (left). These observations together with the strong docking defects for syntaxin and Snap-25 null mutants (as shown in Fig. 1) indicate that besides syntaxin and Munc18-1, also SNAP-25 and synaptotagmin are essential for LDCV docking, and that synaptotagmin-1 binds to SNAP-25 to anchor LDCVs. The scale bar represents $200 \mathrm{~nm}$. b Working model for subsequent steps in the exocytotic pathway.

phenotypes have been observed in null mutants for any of these vesicular proteins. Biochemical evidence suggests that at least two vesicle proteins bind to established docking factors on the plasma membrane and can therefore be considered candidate docking factors: synaptobrevin-2 and synaptotagmin-1 (Chieregatti et al. 2002; Rickman et al. 2004; Schiavo et al. 1997; Söllner et al. 1993). We recently confirmed that the synaptobrevin-2 null mutation does not produce docking phenotypes similar to munc18-1 or syntaxin-1 null (Gerber et al. 2008), consistent with earlier findings (Borisovska et al. 2005). Therefore, we realized that synaptotagmin- 1 is the prime candidate for a vesicular docking protein. Indeed we
Priming

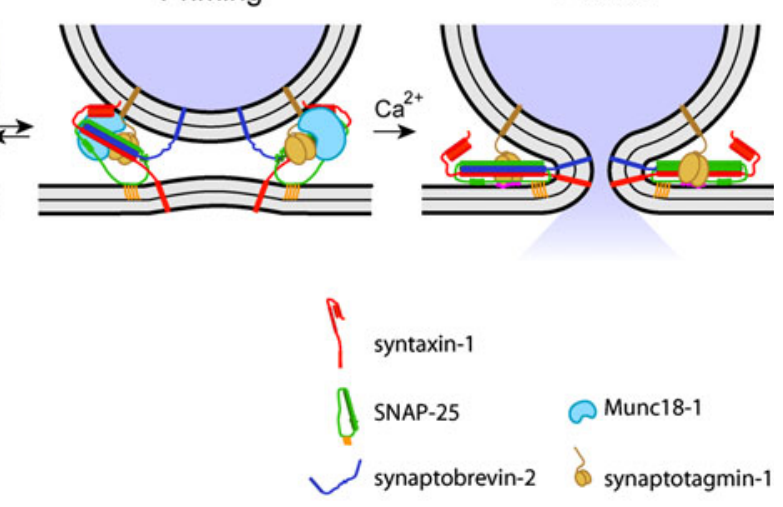

Model depicts the subsequent steps in the pathway, starting with several initial protein complexes consisting of syntaxin-1 (red), SNAP-25 (green) and/or Munc18-1 (light blue), until the final fusion, which also involves synaptobrevin/VAMP (dark blue) and synaptotagmin-1 (yellow). The bottom row indicates non-productive protein complexes, which do not lead to fusion, either by integrating two syntaxins and one SNAP-25 into a single complex (2:1 complex 'off pathway', bottom left) or by formation of a 1:1 syntaxin-1/SNAP-25 complex stabilized by the C-terminal fragment of synaptobrevin-2, with or without synaptotagmin-1 associated (bottom right). Note that complexin-1 is excluded in this model. See (de Wit et al. 2009) and main text for a detailed description of the proposed steps in the pathway. Adapted from (de Wit et al. 2009)

observed a strong docking defect in synaptotagmin-1 null cells, similar to Snap-25 null cells (de Wit et al. 2009). In addition we found that SNAP-25 no longer rescues docking in synaptotagmin-1/munc18-1 double null mutants. By using synaptotagmin-1 and SNAP-25 mutations that affect their interaction we confirmed that synaptotagmin-1 provides the direct link between vesicles and syntaxin-1/SNAP-25 acceptor complexes via interaction of its C2B domain with SNAP-25 (de Wit et al. 2009) (Fig. 3). Together, using EM analysis combined with null mutations and (cross-) rescue experiments we identified two novel proteins, SNAP-25 and synaptotagmin-1 that act in concert with our previously characterized 
proteins Munc18-1 and syntaxin-1 in docking of LDCVs, and that Munc18-1 also plays a unique, orchestrating role.

Currently, it is unknown whether the same docking machinery as we resolved in neuroendocrine cells (de Wit et al. 2009) also acts in synapses. In vertebrate-synapses, docking-phenotypes for munc-18-1/syntaxin-1/Snap-25/ synaptotagmin-1 null are less evident (Verhage and Sørensen 2008) possibly arguing for distinct docking mechanisms. However, recently we observed that heterozygous expression of Munc18-1 reduced the number of docked SVs in cultured hippocampal neurons (Toonen et al. 2006b) (Fig. 4). Therefore, it seems more likely that docking principles are conserved among secretory systems. This idea is strongly supported by observations that invertebrate-synapses have docking-phenotypes upon Munc181/syntaxin-1/synaptotagmin-1 mutations (Hammarlund et al. 2007; Jorgensen et al. 1995; Reist et al. 1998; Weimer and Richmond 2005). However, these phenotypes are generally subtle and sometimes require advanced methodology and new docking definitions to become evident (Hammarlund et al. 2007; Weimer and Richmond 2005). In case of synaptotagmin-1 null mutations, phenotypes have not been specifically interpreted in terms of docking due to additional phenotypes in these invertebrate synapses: large effects on undocked vesicle populations near the active zone (Reist et al. 1998), impaired recycling (Jorgensen et al. 1995) and/or impaired recruitment (Loewen et al. 2006). Interestingly, a mutation used in the latter study is in an area of the molecule that was later identified to interact with SNAP-25 (Rickman et al. 2006). Probably, docking phenotypes are less evident in vertebrate synapses either due to redundancy arising from the expression of multiple isoforms for some of the docking genes identified here or because structurally unrelated proteins, that are not expressed in chromaffin cells, restrict undocking of SVs even when essential docking factors are not expressed. Finally, it is plausible that undocking and docking phenotypes are simply not as evident in the densely packed nerve terminal.

\section{Sub-membrane F-actin controls access of vesicles to docking sites}

Bovine chromaffin cells possess a dense mesh of submembrane F-actin underneath the plasma membrane which is thought to provide a barrier for LDCVs to access exocytotic sites under resting conditions (Nakata and Hirokawa 1992). Consistent with this view perturbations of the sub-membrane F-actin modulate docking and secretion (for reviews see de Wit 2010; Trifaró et al. 2008). Upon a secretory stimulus it seems that two major sub-membrane F-actin severing pathways are activated. The first pathway is controlled by $\mathrm{Ca}^{2+}$ entry that results in activation of scinderin (Zhang et al. 1996) whereas the second pathway depends on protein kinase $\mathrm{C}$ (PKC) activation and phosphorylation of the myristoylated alanine-rich $\mathrm{C}$ kinase substrate (MARCKs) (Vitale et al. 1992). Both scinderin and MARCKS are F-actin severing proteins, and their activation induces a local disruption of the sub-membrane

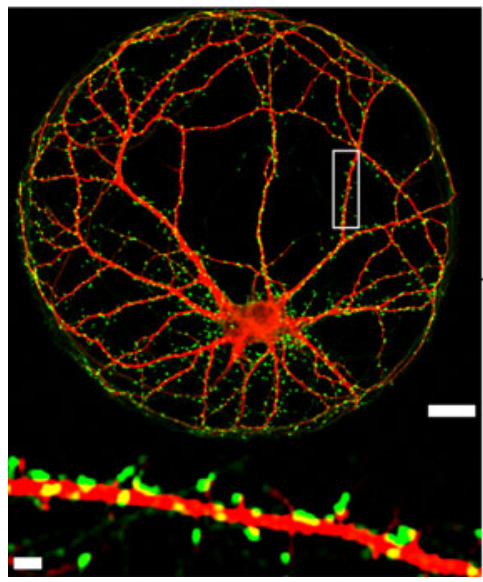

Fig. 4 Morphological docking phenotypes in neurons. Left panel cultured hippocampal neuron grown in islands (making synapses on itself that are also known as autapses) stained for MAP2 (red) and synapsin (green) at DIV 14. The scale bar represents $20 \mu \mathrm{m}$. The bottom shows a higher magnification (scale bar represents $2 \mu \mathrm{m}$ ) of the part indicated by the rectangle (top) of synapsin-stained synapses making synaptic contact with MAP2-stained dendrites. This image was kindly provided by Dr. Toonen. For details see (Wierda et al. 2007). Middle panel schematic representation of synapses showing
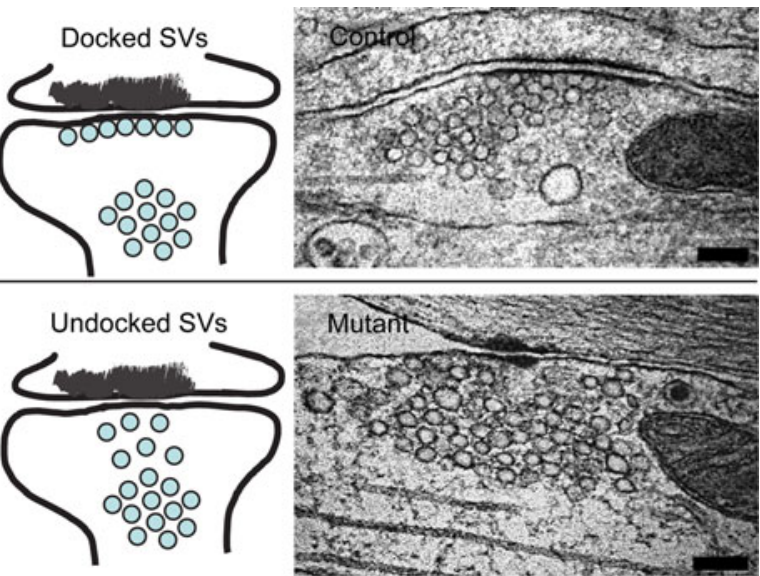

morphological docked (top) and undocked (bottom) SVs, respectively without any $(0 \mathrm{~nm})$ or with $(>0 \mathrm{~nm})$ measurable distance between vesicle and the active zone facing the postsynaptic density. Right panel electron micrograph of an autaptic synapse of a control (wild type) hippocampal neuron (top). Note the array of docked vesicles facing the postsynaptic density. In autapses of heterozygous Munc18 hippocampal neurons less SVs are found docked to the presynaptic membrane (bottom). See also (Toonen et al. 2006b) for details. The scale bar represents $100 \mathrm{~nm}$ 
F-actin architecture to facilitate recruitment of LDCVs towards release sites, however their involvement in docking remains unresolved. Recently we observed that the submembrane F-actin is severely altered in the absence of the docking protein Munc18-1 in embryonic mouse munc18-1 null chromaffin cells (de Wit 2010; Toonen et al. 2006a). Compared to embryonic wild type, munc18 null chromaffin cells contain a denser sub-membrane F-actin network, and only a few vesicles are docked (de Wit 2010; Toonen et al. 2006a) (Fig. 5). Strikingly, Latrunculin A (Lat A) reduced the sub-membrane F-actin, and completely restored docking (Toonen et al. 2006a). Munc18-1 is rapidly phosphorylated by PKC upon depolarization (Craig et al. 2003), and is an important downstream target in PKC-dependent potentiation of secretory vesicle recruitment and release (Wierda et al. 2007). Recently, we observed that phorbol esters can reduce sub-membrane F-actin, and partially restore docking ( $\mathrm{H}$. de Wit unpublished results) and secretion (Gulyás-Kovács et al. 2007) in the absence of Munc18-1. Our observation that phorbol esters only partially restore the docking/secretion defect can be explained by the fact that reduction of the sub-membrane F-actin network alone is not sufficient for functional docking/ secretion, like shown before after Lat A application (Toonen et al. 2006a). Together, this makes Munc18-1 a likely candidate as a downstream target for PKC-dependent reorganization of sub-membrane F-actin to regulate docking. Further experiments are required to see whether Munc18-1 alone is sufficient to rearrange sub-membrane F-actin or whether additional factors are required. For example, previously it was found that Munc18-1 colocalizes with cytoskeleton proteins (Bhaskar et al. 2004) and is phosphorylated by cyclin-dependent kinase (Cdk5), which is found in connection with neurofilaments (Shetty et al. 1995), but it remains to be tested whether Munc18-1 directly acts as an actin-severing protein. Irrespective of

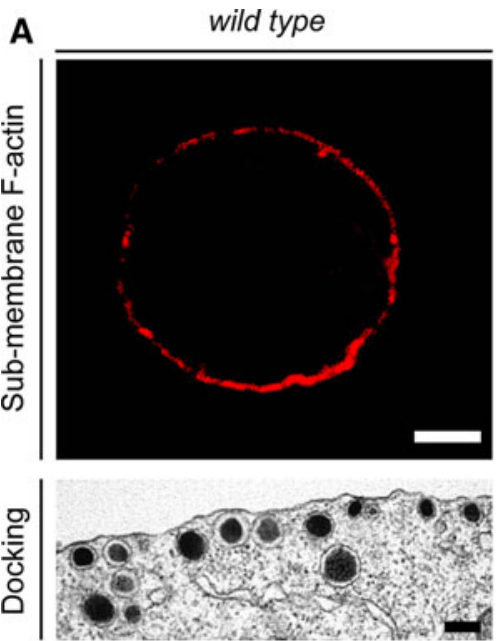

$\%$ intactness of sub-membrane $\mathrm{F}$-actin $0 \quad 10 \quad 20 \quad 30 \quad 40 \quad 50 \quad 60 \quad 70 \quad 80 \quad 90100$

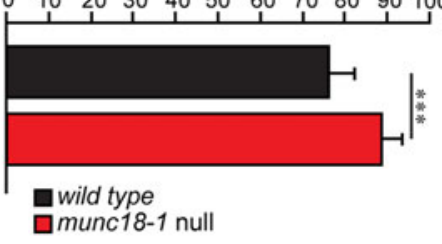

Number of docked vesicles

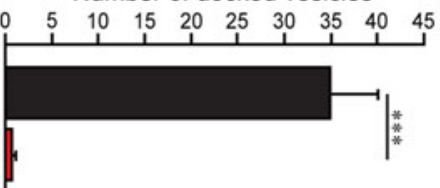

Control

B
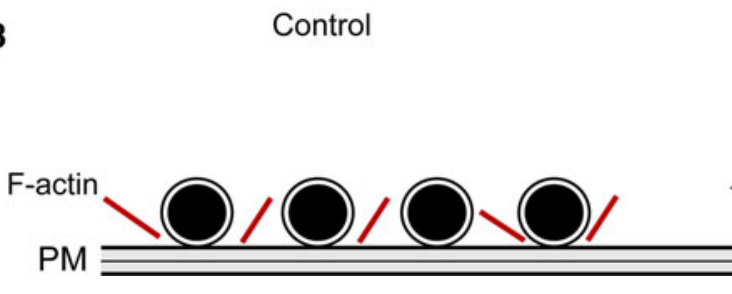

Fig. 5 Comparison of docking and sub-membrane F-actin in chromaffin cells. a Top panel rhodamin-phalloidin staining of submembrane filamentous (F-)actin in a wild type (left) and munc18-1 null (right) chromaffin cell (bar represents $2 \mu \mathrm{m}$ ). In the absence of Munc18-1 the \% of intact sub-membrane F-actin is significantly increased compared to wild type chromaffin cells (middle). Bottom panel in munc18-1 null chromaffin cells fewer LDCVs (right, middle) are docked compared to wild type controls (left, middle) as observed by electron microscopy and might be explained by the differences in intact sub-membrane F-actin (middle). This docking phenotype is the opposite for wild type embryonic chromaffin cells (left). The scale bar represents $100 \mathrm{~nm}$. b Putative cartoon model summarizing the role of Munc18-1 in docking and modulation of sub-membrane F-actin. In embryonic chromaffin cells sub-membrane F-actin is less developed and more vesicles are docked at the plasma membrane (PM) compared to mature chromaffin cells (de Wit 2010; Nili et al. 2006). Upon depolymerization of sub-membrane F-actin stimulated by PKC, Munc18-1 or $\mathrm{Ca}^{2+}$ (e.g. scinderin) LDCVs have easier access to docking sites. We hypothesize that in the absence of Munc18-1 F-actin depolymerization and access to docking sites is severely reduced. In wild type embryonic cells most of these sites are already occupied which is indicated by the mild increase of docked LDCV after overexpression of Munc18-1 in these cells (Toonen et al. 2006a) and also by the strong increase in mature chromaffin cells (de Wit 2010; Nili et al. 2006). Adapted from (de Wit 2010) 
the mechanism it seems that Munc18-1's function here does not depend on binding to syntaxin-1 because syntaxin1 deletion by Botulinum toxin $\mathrm{C}$ (BoNT/C) does not affect the sub-membrane F-actin (de Wit et al. 2006).

Similar to chromaffin cells, synapses seem to have a sub-membrane F-actin network (Dillon and Goda 2005; Doussau and Augustine 2000). F-actin is abundantly distributed throughout the presynaptic terminal and is often associated with the synapsin filaments (Landis et al. 1988) to link SVs (Pieribone et al. 1995). Biochemical (Phillips et al. 2001), ultrastructural (Hirokawa et al. 1989), and functional (Morales et al. 2000) studies indicate that actin also constitutes an important component of the active zone. In hippocampal synapses, Lat A treatment promotes neurotransmitter release, but the readily releasable pool size and its rate of refilling are not altered by Lat A (Morales et al. 2000). This suggests that Lat A exerts its effect on vesicles that are already docked at the active zone. Similarly, actin depolymerizing agents are ineffective in increasing neurotransmitter release in hippocampal slices of mouse harboring a homozygous deletion of the LIM kinase 1 gene $(L I M K-1)$, a kinase that modifies actin dynamics by phosphorylating and thereby inactivating cofilin (Meng et al. 2002). Taken together, these observations suggest that the actin cytoskeleton negatively regulates neurotransmitter release by forming a structural barrier for exocytosis at or near release sites. However, it can be expected that the organization of the actin cytoskeletal network at release sites in chromaffin cell might be different from synapses, probably because their release sites do not contain a subcellular specialization like the active zones in synapses and expression of certain synaptic actin-associated proteins (e.g. synapsins, LIM kinases) is absent (Dillon and Goda 2005; Doussau and Augustine 2000).

In synapses, SV fusion occurs at specialized sites of plasma-membrane, referred to as the presynaptic activezonal-cytometrix (CAZ) that accumulates the molecular machinery to orchestrate SV docking/fusion (Schoch and Gundelfinger 2006). Light-microscopic studies in reduced systems indicate that distribution of essential docking factors is complex, with accumulations of individual factors in partially overlapping microdomains (Lang et al. 2001; Lang and Jahn 2008). However, currently little ultrastructural information is available on distribution of these factors in neurosecretory cells, like chromaffin cells especially not in mutant systems with docking-phenotypes that we previously generated (de Wit et al. 2009). We are planning to study the distribution of docking proteins using immuno-(I)EM on ultrathin cryosections of chemicallyfixed chromaffin cells and synapses (Oorschot et al. 2002). In secretory cells the number of morphological docked vesicles typically exceeds the number of release-ready vesicles (Gulyás-Kovács et al. 2007). Docked vesicles can be in different stages of release-readiness and seems determined by their positioning relative to $\mathrm{Ca}^{2+}$-channels (Sakaba and Neher 2001); however, ultrastructural evidence for this is currently unavailable and which genes modulate this positioning is unknown. The 3D-reconstructions of frog neuromuscular junction and rat brain synaptosomes revealed readily-releasable-pool (RRP) organization and identified protein-linkages (FernandezBusnadiego et al. 2010; Harlow et al. 2001; Rizzoli and Betz 2004) that could presumably dock SVs in proximity to $\mathrm{Ca}^{2+}$-channels. Pharmacological manipulations were show to affect these linkages, but the molecular identity of these tethers remains unclear and as a consequence the molecular mechanism how these protein-linkages function in nanometer-distance positioning of $\mathrm{SVs}$ to $\mathrm{Ca}^{2+}$-channels is unknown. Electron-tomography also revealed that SVs associate to sub-membranous cytoskeleton inside CAZ (Rostaing et al. 2006; Siksou et al. 2007) and seems to play a central role in LDCV docking in neuroendocrine cells (Toonen et al. 2006a) and synapses (Siksou et al. 2007). Taken together novel EM approaches are required to investigate whether the previously identified protein-linkages are composed of our four identified docking proteins. In the end, this will help to characterize the molecular mechanism of secretory vesicle docking in the proximity of $\mathrm{Ca}^{2+}$-channels and relate this to release-readiness and how this positioning is controlled by the sub-membrane actin.

\section{Concluding remarks}

In conclusion, we show that docking is established between syntaxin-1/SNAP-25 acceptor complexes at the target membrane and synaptotagmin-1 on the vesicle membrane. Munc18-1 promotes the formation of a 1:1 syntaxin-1/ SNAP-25 acceptor complexes and is capable of determining the number of docking sites by modulating sub-membrane F-actin. In addition to a role in docking we observed that Munc18-1 plays a critical function in the downstream events that lead to membrane fusion. The importance of these docking proteins is illustrated by the fact that they are strongly linked to brain disorders, in particular neurodegenerative diseases (Ghiani et al. 2010; Greber et al. 1999) and mental illnesses like attention-deficits (McKee et al. 2010), and also associate with intelligence (Gosso et al. 2006). Currently, it is unclear how these docking proteins operate in synapses and regulate $\mathrm{SV}$ docking near $\mathrm{Ca}^{2+}$. channels. In addition it is unknown how the unique composition of sub-membrane cytoskeleton may help to orchestrate this docking process. Advanced imaging experiments are required to unravel possible differences in docking phenotypes between chromaffin cells as well as neurons and determine whether the same docking 
machinery is used during neurotransmitter release at neuronal active zones. This difference has probably evolved to keep docking sites available during certain stimulatory demands. Finally, these future studies will help to resolve how our four identified docking proteins orchestrate the docking process and will improve our understanding of neurological disorders linked to these docking genes in human brain.

Acknowledgments I would like to thank Joke Wortel, Rien Dekker, Tony Cijsouw, Robbert Zalm, Ingrid Saarloos, Joost Hoetjes, Desiree Schut, Ina Herfort, and Dirk Reuter for excellent technical assistance. I am also grateful to Matthijs Verhage, Ruud Toonen, and Sander Groffen for fruitful discussions. Also I like to give special thanks to Tom Südhof, Uri Ashery, Bazbek Davletov, Dirk Fasshauer, Jakob Sørensen, Alexander Walter, Ralf Mohrmann, and Erwin Neher for support and collaborations. This work presented here has received financial support by grants from the NeuroBsik Mouse Phenomics Consortium (BSIK03053), the European Commission (EU Synapse project, LSHM-CT-2005-019055) and the Netherlands Organization for Scientific Research, NWO (VENI 916-36-043).

Open Access This article is distributed under the terms of the Creative Commons Attribution Noncommercial License which permits any noncommercial use, distribution, and reproduction in any medium, provided the original author(s) and source are credited.

\section{References}

Ashery U, Varoqueaux F, Voets T, Betz A, Thakur P, Koch H, Neher E, Brose N, Rettig J (2000) Munc13-1 acts as a priming factor for large dense-core vesicles in bovine chromaffin cells. EMBO J 19:3586-3596

Barclay JW (2008) Munc-18-1 regulates the initial release rate of exocytosis. Biophys J 94:1084-1093

Bhaskar K, Shareef MM, Sharma VM, Shetty AP, Ramamohan Y, Pant HC, Raju TR, Shetty KT (2004) Co-purification and localization of Munc18-1 (p67) and Cdk5 with neuronal cytoskeletal proteins. Neurochem Int 44:35-44

Borisovska M, Zhao Y, Tsytsyura Y, Glyvuk N, Takamori S, Matti U, Rettig J, Südhof T, Bruns D (2005) v-SNAREs control exocytosis of vesicles from priming to fusion. EMBO J 24:2114-2126

Burkhardt P, Hattendorf DA, Weis WI, Fasshauer D (2008) Munc18a controls SNARE assembly through its interaction with the syntaxin N-peptide. EMBO J 27:923-933

Chieregatti E, Witkin JW, Baldini G (2002) SNAP-25 and synaptotagmin 1 function in $\mathrm{Ca} 2+$-dependent reversible docking of granules to the plasma membrane. Traffic 3:496-511

Craig TJ, Evans GJ, Morgan A (2003) Physiological regulation of Munc18/nSec1 phosphorylation on serine-313. J Neurochem 86:1450-1457

de Wit H (2010) Molecular mechanism of secretory vesicle docking. Biochem Soc Trans 38:192-198

de Wit H, Cornelisse LN, Toonen RF, Verhage M (2006) Docking of secretory vesicles is syntaxin dependent. PLoS ONE 1:e126

de Wit H, Walter AM, Milosevic I, Gulyas-Kovacs A, Riedel D, Sorensen JB, Verhage M (2009) Synaptotagmin-1 docks secretory vesicles to syntaxin-1/SNAP-25 acceptor complexes. Cell 138:935-946
Deak F, Xu Y, Chang WP, Dulubova I, Khvotchev M, Liu X, Sudhof TC, Rizo J (2009) Munc18-1 binding to the neuronal SNARE complex controls synaptic vesicle priming. J Cell Biol 184:751764

Dillon C, Goda Y (2005) The actin cytoskeleton: integrating form and function at the synapse. Annu Rev Neurosci 28:25-55

Doussau F, Augustine GJ (2000) The actin cytoskeleton and neurotransmitter release: an overview. Biochimie 82:353-363

Dulubova I, Sugita S, Hill S, Hosaka M, Fernandez I, Südhof TC, Rizo J (1999) A conformational switch in syntaxin during exocytosis: role of munc18. EMBO J 18:4372-4382

Dulubova I, Khvotchev M, Liu S, Huryeva I, Südhof TC, Rizo J (2007) Munc18-1 binds directly to the neuronal SNARE complex. Proc Natl Acad Sci U S A 104:2697-2702

Fasshauer D, Margittai M (2004) A transient N-terminal interaction of SNAP-25 and syntaxin nucleates SNARE assembly. J Biol Chem 279:7613-7621

Fernandez-Busnadiego R, Zuber B, Maurer UE, Cyrklaff M, Baumeister W, Lucic V (2010) Quantitative analysis of the native presynaptic cytomatrix by cryoelectron tomography. J Cell Biol 188:145-156

Ferro-Novick S, Jahn R (1994) Vesicle fusion from yeast to man. Nature 370:191-193

Gerber SH, Rah JC, Min SW, Liu X, de Wit H, Dulubova I, Meyer AC, Rizo J, Arancillo M, Hammer RE, Verhage M, Rosenmund C, Südhof TC (2008) Conformational switch of syntaxin-1 controls synaptic vesicle fusion. Science 321:15071510

Ghiani CA, Starcevic M, Rodriguez-Fernandez IA, Nazarian R, Cheli VT, Chan LN, Malvar JS, de Vellis J, Sabatti C, Dell'Angelica EC (2010) The dysbindin-containing complex (BLOC-1) in brain: developmental regulation, interaction with SNARE proteins and role in neurite outgrowth. Mol Psychiatry 15:115, 204-115

Gosso MF, de Geus EJ, van Belzen MJ, Polderman TJ, Heutink P, Boomsma DI, Posthuma D (2006) The SNAP-25 gene is associated with cognitive ability: evidence from a family-based study in two independent Dutch cohorts. Mol Psychiatry 11:878886

Greber S, Lubec G, Cairns N, Fountoulakis M (1999) Decreased levels of synaptosomal associated protein 25 in the brain of patients with Down syndrome and Alzheimer's disease. Electrophoresis 20:928-934

Gulyás-Kovács A, de Wit H, Milosevic I, Kochubey O, Toonen R, Klingauf J, Verhage M, Sørensen JB (2007) Munc18-1: sequential interactions with the fusion machinery stimulate vesicle docking and priming. J Neurosci 27:8676-8686

Hammarlund M, Palfreyman MT, Watanabe S, Olsen S, Jorgensen EM (2007) Open syntaxin docks synaptic vesicles. PLoS Biol 5:e198

Harlow ML, Ress D, Stoschek A, Marshall RM, McMahan UJ (2001) The architecture of active zone material at the frog's neuromuscular junction. Nature 409:479-484

Hata Y, Südhof TC (1995) A novel ubiquitous form of Munc-18 interacts with multiple syntaxins. Use of the yeast two-hybrid system to study interactions between proteins involved in membrane traffic. J Biol Chem 270:13022-13028

Hirokawa N, Sobue K, Kanda K, Harada A, Yorifuji H (1989) The cytoskeletal architecture of the presynaptic terminal and molecular structure of synapsin 1. J Cell Biol 108:111-126

Jahn R (2000) Sec1/Munc18 proteins: mediators of membrane fusion moving to center stage. Neuron 27:201-204

Jahn R, Scheller RH (2006) SNAREs-engines for membrane fusion. Nat Rev Mol Cell Biol 7:631-643

Jorgensen EM, Hartwieg E, Schuske K, Nonet ML, Jin Y, Horvitz HR (1995) Defective recycling of synaptic vesicles in synaptotagmin mutants of C. elegans. Nature 378:196-198 
Khvotchev M, Dulubova I, Sun J, Dai H, Rizo J, Südhof TC (2007) Dual modes of Munc18-1/SNARE interactions are coupled by functionally critical binding to syntaxin-1 $\mathrm{N}$ terminus. J Neurosci 27:12147-12155

Landis DM, Hall AK, Weinstein LA, Reese TS (1988) The organization of cytoplasm at the presynaptic active zone of a central nervous system synapse. Neuron 1:201-209

Lang T, Jahn R (2008) Core proteins of the secretory machinery. Handb Exp Pharmacol 184:107-127

Lang T, Bruns D, Wenzel D, Riedel D, Holroyd P, Thiele C, Jahn R (2001) SNAREs are concentrated in cholesterol-dependent clusters that define docking and fusion sites for exocytosis. EMBO J 20:2202-2213

Latham CF, Lopez JA, Hu SH, Gee CL, Westbury E, Blair DH, Armishaw CJ, Alewood PF, Bryant NJ, James DE, Martin JL (2006) Molecular dissection of the Munc18c/syntaxin4 interaction: implications for regulation of membrane trafficking. Traffic 7:1408-1419

Loewen CA, Lee SM, Shin YK, Reist NE (2006) C2B polylysine motif of synaptotagmin facilitates a $\mathrm{Ca}^{2+}$-independent stage of synaptic vesicle priming in vivo. Mol Biol Cell 17:5211-5226

Malacombe M, Bader MF, Gasman S (2006) Exocytosis in neuroendocrine cells: new tasks for actin. Biochim Biophys Acta 1763:1175-1183

Martin-Verdeaux S, Pombo I, Iannascoli B, Roa M, Varin-Blank N, Rivera J, Blank U (2003) Evidence of a role for Munc18-2 and microtubules in mast cell granule exocytosis. J Cell Sci 116:325334

McKee AG, Loscher JS, O'Sullivan NC, Chadderton N, Palfi A, Batti L, Sheridan GK, O'Shea S, Moran M, McCabe O, Fernandez $\mathrm{AB}$, Pangalos MN, O'Connor JJ, Regan CM, O'Connor WT, Humphries P, Farrar GJ, Murphy KJ (2010) AAV-mediated chronic over-expression of SNAP-25 in adult rat dorsal hippocampus impairs memory-associated synaptic plasticity. J Neurochem 112:991-1004

Meng Y, Zhang Y, Tregoubov V, Janus C, Cruz L, Jackson M, Lu WY, MacDonald JF, Wang JY, Falls DL, Jia Z (2002) Abnormal spine morphology and enhanced LTP in LIMK-1 knockout mice. Neuron 35:121-133

Morales M, Colicos MA, Goda Y (2000) Actin-dependent regulation of neurotransmitter release at central synapses. Neuron 27:539550

Morgan A, Burgoyne RD (1997) Common mechanisms for regulated exocytosis in the chromaffin cell and the synapse. Semin Cell Dev Biol 8:141-149

Nakata T, Hirokawa N (1992) Organization of cortical cytoskeleton of cultured chromaffin cells and involvement in secretion as revealed by quick-freeze, deep-etching, and double-label immunoelectron microscopy. J Neurosci 12:2186-2197

Naren AP, Nelson DJ, Xie W, Jovov B, Pevsner J, Bennett MK, Benos DJ, Quick MW, Kirk KL (1997) Regulation of CFTR chloride channels by syntaxin and munc 18 isoforms. Nature 390:302-305

Nili U, de Wit H, Gulyas-Kovacs A, Toonen RF, Sørensen JB, Verhage M, Ashery U (2006) Munc18-1 phosphorylation by protein kinase $\mathrm{C}$ potentiates vesicle pool replenishment in bovine chromaffin cells. Neuroscience 143:487-500

Oorschot V, de Wit H, Annaert WG, Klumperman J (2002) A novel flat-embedding method to prepare ultrathin cryosections from cultured cells in their in situ orientation. J Histochem Cytochem 50:1067-1080

Phillips GR, Huang JK, Wang Y, Tanaka H, Shapiro L, Zhang W, Shan WS, Arndt K, Frank M, Gordon RE, Gawinowicz MA, Zhao Y, Colman DR (2001) The presynaptic particle web: ultrastructure, composition, dissolution, and reconstitution. Neuron 32:63-77
Pieribone VA, Shupliakov O, Brodin L, Hilfiker S, Czernik AJ, Greengard P (1995) Distinct pools of synaptic vesicles in neurtransmitter release. Nature 375:493-496

Pobbati AV, Stein A, Fasshauer D (2006) N- to C-terminal SNARE complex assembly promotes rapid membrane fusion. Science 313:673-676

Reist NE, Buchanan J, Li J, DiAntonio A, Buxton EM, Schwarz TL (1998) Morphologically docked synaptic vesicles are reduced in synaptotagmin mutants of Drosophila. J Neurosci 18:76627673

Rickman C, Archer DA, Meunier FA, Craxton M, Fukuda M, Burgoyne RD, Davletov B (2004) Synaptotagmin interaction with the syntaxin/SNAP-25 dimer is mediated by an evolutionarily conserved motif and is sensitive to inositol hexakisphosphate. J Biol Chem 279:12574-12579

Rickman C, Jimenez JL, Graham ME, Archer DA, Soloviev M, Burgoyne RD, Davletov B (2006) Conserved prefusion protein assembly in regulated exocytosis. Mol Biol Cell 17:283-294

Riento K, Kauppi M, Keranen S, Olkkonen VM (2000) Munc18-2, a functional partner of syntaxin 3, controls apical membrane trafficking in epithelial cells. J Biol Chem 275:13476-13483

Rizo J, Rosenmund C (2008) Synaptic vesicle fusion. Nat Struct Mol Biol 15:665-674

Rizzoli SO, Betz WJ (2004) The structural organization of the readily releasable pool of synaptic vesicles. Science 303:2037-2039

Rostaing P, Real E, Siksou L, Lechaire JP, Boudier T, Boeckers TM, Gertler F, Gundelfinger ED, Triller A, Marty S (2006) Analysis of synaptic ultrastructure without fixative using high-pressure freezing and tomography. Eur J Neurosci 24:3463-3474

Sakaba T, Neher E (2001) Quantitative relationship between transmitter release and calcium current at the calyx of held synapse. J Neurosci 21:462-476

Schiavo G, Stenbeck G, Rothman JE, Söllner T (1997) Binding of the synaptic vesicle $\mathrm{v}$-SNARE, synaptotagmin, to the plasma membrane t-SNARE SNAP-25, can explain docked vesicles at neurotoxin-treated synapses. Proc Natl Acad Sci USA 94:9971001

Schoch S, Gundelfinger ED (2006) Molecular organization of the presynaptic active zone. Cell Tissue Res 326:379-391

Schoch S, Deak F, Konigstorfer A, Mozhayeva M, Sara Y, Sudhof TC, Kavalali ET (2001) SNARE function analyzed in synaptobrevin/VAMP knockout mice. Science 294:1117-1122

Schütz D, Zilly F, Lang T, Jahn R, Bruns D (2005) A dual function for Munc-18 in exocytosis of PC12 cells. Eur J Neurosci 21:2419-2432

Shen J, Tareste DC, Paumet F, Rothman JE, Melia TJ (2007) Selective activation of cognate SNAREpins by Sec1/Munc18 proteins. Cell 128:183-195

Shetty KT, Kaech S, Link WT, Jaffe H, Flores CM, Wray S, Pant HC, Beushausen S (1995) Molecular characterization of a neuronalspecific protein that stimulates the activity of Cdk5. J Neurochem 64:1988-1995

Siksou L, Rostaing P, Lechaire JP, Boudier T, Ohtsuka T, Fejtova A, Kao HT, Greengard P, Gundelfinger ED, Triller A, Marty S (2007) Three-dimensional architecture of presynaptic terminal cytomatrix. J Neurosci 27:6868-6877

Söllner T, Whiteheart S, Brunner M, Bromage H, Geromanos S, Tempst P, Rothman JE (1993) SNAP receptors implicated in vesicle targeting and fusion. Nature 362:318-323

Sørensen JB, Nagy G, Varoqueaux F, Nehring RB, Brose N, Wilson MC, Neher E (2003) Differential control of the releasable vesicle pools by SNAP-25 splice variants and SNAP-23. Cell 114:75-86

Sørensen JB, Wiederhold K, Muller EM, Milosevic I, Nagy G, de Groot BL, Grubmuller H, Fasshauer D (2006) Sequential N- to C-terminal SNARE complex assembly drives priming and fusion of secretory vesicles. EMBO J 25:955-966 
Takamori S, Holt M, Stenius K, Lemke EA, Gronborg M, Riedel D, Urlaub H, Schenck S, Brugger B, Ringler P, Muller SA, Rammner B, Grater F, Hub JS, De Groot BL, Mieskes G, Moriyama Y, Klingauf J, Grubmuller H, Heuser J, Wieland F, Jahn R (2006) Molecular anatomy of a trafficking organelle. Cell 127:831-846

Tellam JT, McIntosh S, James DE (1995) Molecular identification of two novel Munc-18 isoforms expressed in non-neuronal tissues. J Biol Chem 270:5857-5863

Tellam JT, Macaulay SL, McIntosh S, Hewish DR, Ward CW, James DE (1997) Characterization of Munc-18c and syntaxin-4 in 3T3L1 adipocytes. Putative role in insulin-dependent movement of GLUT-4. J Biol Chem 272:6179-6186

Toonen RF, Verhage M (2007) Munc18-1 in secretion: lonely Munc joins SNARE team and takes control. Trends Neurosci 30:564572

Toonen RF, Kochubey O, de Wit H, Gulyas-Kovacs A, Konijnenburg B, Sørensen JB, Klingauf J, Verhage M (2006a) Dissecting docking and tethering of secretory vesicles at the target membrane. EMBO J 25:3725-3737

Toonen RF, Wierda K, Sons MS, de Wit H, Cornelisse LN, Brussaard A, Plomp JJ, Verhage M (2006b) Munc18-1 expression levels control synapse recovery by regulating readily releasable pool size. Proc Natl Acad Sci U S A 103:18332-18337

Trifaró JM, Gasman S, Gutierrez LM (2008) Cytoskeletal control of vesicle transport and exocytosis in chromaffin cells. Acta Physiol (Oxf) 192:165-172

van Weering JR, Toonen RF, Verhage M (2007) The role of Rab3a in secretory vesicle docking requires association/dissociation of guanidine phosphates and Munc18-1. PLoS ONE 2:e616

van Weering JR, Wijntjes R, de Wit H, Wortel J, Cornelisse LN, Veldkamp WJ, Verhage M (2008) Automated analysis of secretory vesicle distribution at the ultrastructural level. J Neurosci Methods 173:83-90
Verhage M, Sørensen JB (2008) Vesicle docking in regulated exocytosis. Traffic 9:1414-1424

Verhage M, Maia AS, Plomp JJ, Brussaard AB, Heeroma JH, Vermeer H, Toonen RF, Hammer RE, van den Berg TK, Missler M, Geuze HJ, Sudhof TC (2000) Synaptic assembly of the brain in the absence of neurotransmitter secretion. Science 287:864-869

Vitale ML, Rodriguez Del Castillo A, Trifaró JM (1992) Protein kinase $\mathrm{C}$ activation by phorbol esters induces chromaffin cell cortical filamentous actin disassembly and increases the initial rate of exocytosis in response to nicotinic receptor stimulation. Neuroscience 51:463-474

Voets T, Toonen RF, Brian EC, de Wit H, Moser T, Rettig J, Südhof TC, Neher E, Verhage M (2001) Munc18-1 promotes large dense-core vesicle docking. Neuron 31:581-591

Wadel K, Neher E, Sakaba T (2007) The coupling between synaptic vesicles and $\mathrm{Ca}(2+)$ channels determines fast neurotransmitter release. Neuron 53:563-575

Walter AM, Wiederhold K, Bruns D, Fasshauer D, Sorensen JB (2010) Synaptobrevin N-terminally bound to syntaxin-SNAP-25 defines the primed vesicle state in regulated exocytosis. J Cell Biol 188:401-413

Weimer RM, Richmond JE (2005) Synaptic vesicle docking: a putative role for the Munc18/Sec1 protein family. Curr Top Dev Biol 65:83-113

Wierda KD, Toonen RF, de Wit H, Brussaard AB, Verhage M (2007) Interdependence of PKC-dependent and PKC-independent pathways for presynaptic plasticity. Neuron 54:275-290

Zhang L, Marcu MG, Nau-Staudt K, Trifaró JM (1996) Recombinant scinderin enhances exocytosis, an effect blocked by two scinderin-derived actin-binding peptides and PIP2. Neuron 17:287-296

Zilly FE, Sørensen JB, Jahn R, Lang T (2006) Munc18-bound syntaxin readily forms SNARE complexes with synaptobrevin in native plasma membranes. PLoS Biol 4:e330 